\title{
Spontaneous Ileo-Ileal And Ileo-Caecal Intussusception In Adults: Report of Two Cases.
}

\author{
Erişkinde Spontan Ileo-Ileal ve Ileo-Çekal \\ Intussussepsiyon: Iki Olgu Sunumu.
}

\section{Erdal Uysal', Mehmet Dokur², Ahmet Orhan Gürer', Hasan Bakır', Mehmet Ali İkidağ}

${ }^{1}$ Private Sani Konukoğlu Hospital,department of General Surgery, Gaziantep,Turkey

${ }^{2}$ Private Sani Konukoğlu Hospital,department of Emergency Medicine, Gaziantep,Turkey

${ }^{3}$ Private Sani Konukoğlu Hospital,department of Radiodiagnostic, Gaziantep,Turkey

Yazışma Adresi / Corresponding to:

Uzm. Dr. Erdal Uysal İncilipınar Mah. Ali Fuat Cebesoy Bulvarı No: 45- Şehitkamil 27090 Gaziantep - Türkiye GSM: 5064845803 e-mail drerdaluysal@hotmail.com

Having defined as a proximal intestinal segment interpenetrating an adjacent distal intestinal segment lumen in the gastrointestinal system intussusception or invagination, is the most common cause for acute abdomen in children following acute appendicitis.Contrary to childhood period intussusception is rarely encountered among adults. Etiology, clinical presentation and treatment methods are different in adults as well. In etiology of an adult intussusception mostly there are malignant, non-malignant and iatrogenik reasons. In rare cases the etiology is idiopathic or spontaneous. Spontaneous intussusceptions are mostly seen in small bowel. Diagnose of an adult intussusception can be overlooked or delayed when it is rarely encountered and atypically presented. Treatment is surgical in most cases. In this article, two adult cases of spontaneous ileo-ileal and ileo-caecal intussusception was analysed and presented under current literature considering clinical outlook, diagnose and treatment.

Keywords: spontaneous intussusception, adult, ileum, caecum

Proksimal barsak segmentinin komşu distal barsak segmenti içerisine penetrasyonu olarak tanımlanan gastrointestinal intussussepsiyonu veya invajinasyonu,çocuklarda akut apandisitten sonra akut batının en sık nedenidir. Çocukluk döneminin aksine erişkinlerde barsak intussussepsiyonları daha az görülür. Erişkin intussussepsiyonlarının etyoloji, klinik prezentasyon ve tedavi yöntemleri de farklıdır. Erişkinlerin barsak intussussepsiyonlarının etyolojisinde çoğunlukla malignant, non-malignant ve iyatrojenik bir neden vardır. Çok az olguda intussussepsiyonun etyolojisi idyopatik ya da spontandır. Spontan olarak gelişen intussussepsiyonlar çoğunlukla ince barsakta görülür. Erişkin intussussepsiyonun tanısı, nadir karşılaşılması ve atipik prezentasyonlu olması nedenleriyle atlanabilir ya da geç konulabilir. Olguların hemen hepsinde tedavi cerrahidir. Bu yazıda spontan ileo-ileal ve ileo-çekal intussussepsiyonlu iki erişkin olgu klinik görünüm, tanı ve tedavi açııından güncel literatür ışı̆ında gözden geçirilerek sunuldu. 


\section{Intoduction:}

While intussusceptions make $0.02-0.003 \%$ of all applications to the hospital, they are merely responsible for $1-3 \%$ of bowel obstructions requiring surgery ${ }^{1-3}$. Organic lesions, inflammatory intestinal diseases, Meckel diverticula, abdominal trauma, surgical interventions, benign, malign and metastatic tumors are responsible for $80-90 \%$ of adult intussusceptions ${ }^{4-7}$. $8-20 \%$ of adult intussusceptions is idiopathic etiology and mainly located in the small intestine ${ }^{8}$. Common vomiting, abdominal pain and bloody stool triad are seen merely in $15-20 \%$ of adults 9 . Direct radiological imaging(DRI) may be diagnostic with regard to showing the ileus. Ultrasonography(US) is supports the diagnosis. However, the most sensitive diagnostic method is abdominal computerized tomography $(\mathrm{CT}),{ }^{10,11}$. There is no specific laboratory finding of intestinal intussusceptions. It is possible to detect elevated leukocytosis and C-reactive protein(CRP), ${ }^{12}$. The treatment is surgery in almost all cases. While the reduction prior to resection in surgical treatment is questionable, it is possible to reduce the non-complicated small intestine intussusceptions. Reduction is questionable particularly in colonic intussusceptions ${ }^{13-15}$

\section{Case Reports}

\section{Case 1}

A female patient at the age of 35 was admitted to our emergency service with complaints of abdominal swelling nonreducing for 6 days, inability to defecate, nausea and vomiting. Her medical history revealed that she applied to another center with same complaints and she was interned and monitored for day three with ileus diagnosis. No prior disease and operation history was detected in her background check. No characteristics were detected related to the case in her family history.

The case was brought with nasogastric catheter inserted and the physical examination revealed moderate dehydration, abdominal distension and sensitivity with deep palpation. There were no rebounds and defenses. There were no palpable abdominal masses. Intestinal peristaltic sounds were detected as lowered. The ampulla in rectal touch was empty. Other system examinations were normal. Generalized air-fluid levels were observed in abdominal DRI(figure 1a). Abdominal free fluid, generalized distension and air-fluid levels in intestinal segments and typical target or sausage-shaped lesion of ileal intussusception were scanned in all contrast enhanced abdominal CT's. It is seen that there is no passage of contrast matter to distal intestinal anses(figure $1 \mathrm{~b}$ and $1 \mathrm{c}$ ). Moderate decrease in hemoglobin-hematocrit(10.2 g/L-30.8\%), protein and albumin (4.2 g/dL and $1.9 \mathrm{~g} / \mathrm{dL})$ as well as elevated platelet $(411000 / \mathrm{mmL}, \mathrm{CRP}(16.6 \mathrm{mg} / \mathrm{dL})$ and mild hypocalcae$\mathrm{mia}(7.5 \mathrm{mg} / \mathrm{dL})$ were detected in laboratory analyses. There was no electrolyte imbalance. Hepatitis markers were detected as negative.

The case was taken into emergency surgery following the preoperative preparation with ileo-ileal intussusception diagnosis. Explorative laparotomy was performed on the case and severe dilated small intestine segments, abdominal free-fluid with serous characteristics and invaginated ileal segment in the proximal with a distance of approximately $35 \mathrm{~cm}$ from the ileo-ceacal valve were detected. Necrosis and perforations were observed when the small intestine segments in the region were explored(figure $1 \mathrm{~d}$ and $1 \mathrm{e})$. Hence $60 \mathrm{~cm}$ section of the ileum was resected and primer anastomosis was performed. There were no complications in post-operative followup of the case.
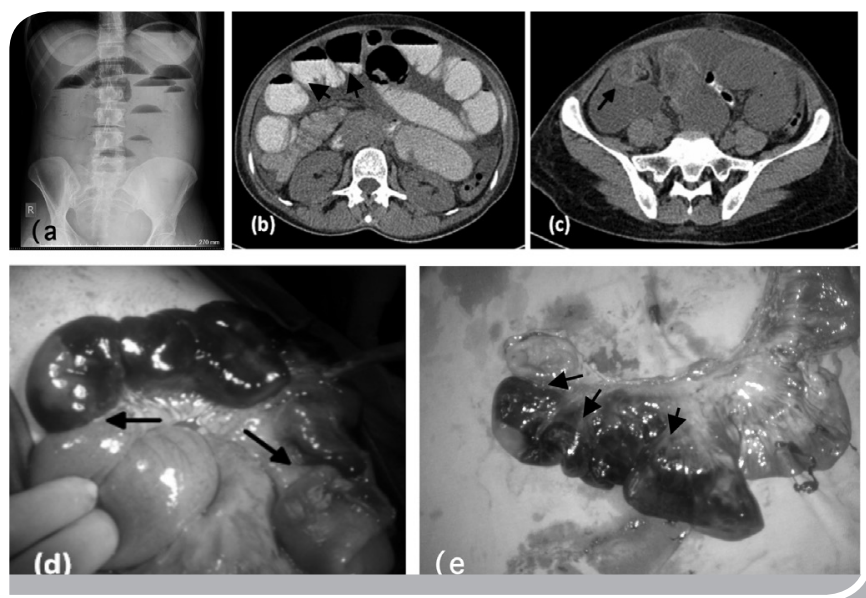

Figure 1:

(a). Ileus linked generalized air-fluid levels view in abdominal DRI (b) and (c). Generalized distension and air-fluid levels view in intestinal segments abdominal CT and typical target (sausage-shape) view of ileo-ileal invagination in distal ileum. (d). Ileal necrosis and perforation regions linked to ileo-ileal invagination. (e). $60 \mathrm{~cm}$ distal ileal ans with resected necrosis and perforations. 


\section{Case 2}

A female patient at the age of 38 applied to our emergency service with complaints of abdominal pain, nausea, vomiting and rectal bleeding. Her medical history revealed that the complaints were ongoing for 2-3 days. Her background revealed that she was a hyperthyroid patient a year ago, underwent goiter operation and still under anti-thyroid treatment. No characteristics were detected in her family history. Her physical examination revealed apparent voluntary defense, sensitivity and rebound in right lower quadrant. No palpable masses were detected in the abdomen. Intestinal peristaltic sounds were detected as slightly increased. The ampulla in rectal touch was empty.

Other system examinations were assessed as normal. No ileus compliant finding was detected in direct abdominal DRI. A view compliant with invagination at ileum distal level (pseudo-kidney image) and proximal intestinal segments filled with fluid and distended were revealed in the abdominal US (figure $2 a$ and $2 b$ ). While a typical target or sausage-shaped lesion compliant with the invagination in $8 \mathrm{~cm}$ intestine segment at abdominal ileum distal segment level and the proximal small intestine segments filled with fluid and distended were detected in all contrast enhanced abdominal CT's, the colon segments were scanned as empty(figure $2 \mathrm{c}$ and $2 \mathrm{~d}$ ). Laboratory analyses of the case revealed slightly elevated plasma free $\mathrm{T3}$ and free T4 levels and slightly decreased TSH level. Otherwise there were no abnormal hematologic and biochemical findings. Hepatitis markers were detected as negative.

The case was taken into emergency operation with ileo-ceacal intussusception diagnosis and the exploratory laparotomy performed revealed small amount of reactional fluid in the abdomen, dilatation in small intestine and $20 \mathrm{~cm}$ section of the terminal ileum is invaginated towards cecum in the ileoceacal valve (figure 2e). No malnutrition, mass and any lesions were detected in the explored distal ileum and cecum regions (figure 2f). The ileo-ceacal intussusception leading from distal ileum to cecum was manually reduced. There were no complications in post-operative early period follow-up of the case.

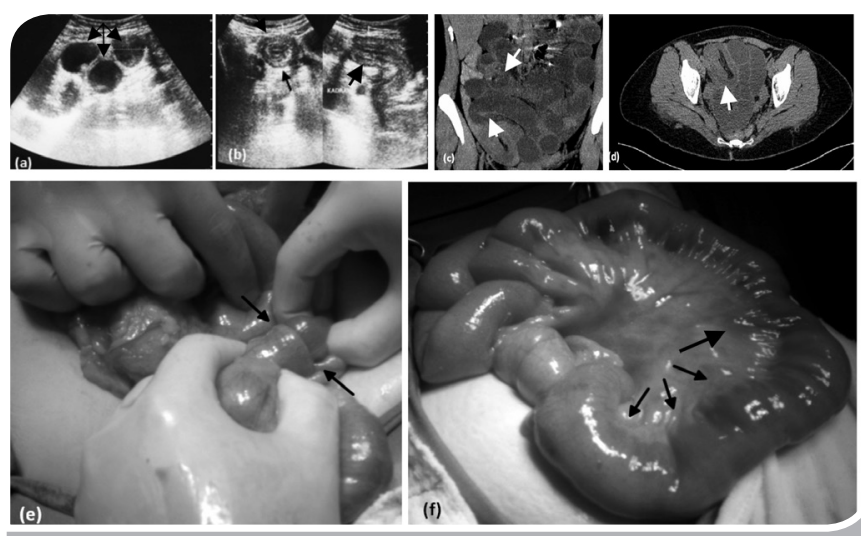

Figure 2:

(a) and (b). Dilated intestinal anses in distal ileum and invagination image in terminal ileum in abdominal US.

(c) and (d). Typical image of ileo-ceacal invagination in two different axial cross-sections in Abdominal CT.

(e) and (f). Manual reduction of ileo-ceacal invagination and postreduction ileo-ceacal invagination and hyperemic image of ileal anses in the proximal.

\section{Discussion}

Adult intussusceptions differ from childhood era intussusceptions in terms of having a different clinical presentation. While there is no known etiology of intussusception in 95\% of the pediatric cases, the etiology in adults is idiopathic in merely $8-20 \%$ of the cases. $65 \%$ of adult intussusceptions consist of benign or malign neoplasms. The expansion of Peyer plaques in the small intestine is deemed responsible for the etiology in $50 \%$ of pediatric intussusception cases. The age average for adult intussusception is 45-51. Gender distribution in our cases is frequently equal ${ }^{1-4,8,13,16}$. While $90 \%$ of adult intussusceptions are encountered in small and large intestine, 10\% occurs in stomach or on surgical stoma formed. Colo-anal intussusceptions are rare and mainly caused by benign or malign lesions. $50 \%$ of these lesions have malign characteristics and rectal prolapsus differential diagnosis is required ${ }^{17,18}$. Benign colonic and intestinal lipomas, mainly encountered in colon and small intestine of older patients, may cause intussusception as well ${ }^{19}$. Furthermore, encountered more frequently in 5th and 6th decades, inflammatory fibroid polyps characterized with eosinophilic infiltration and intense vascularized fibrocystic from benign structured sub mucosal lesions may be encountered as an etiologic agent in small intestine intussusceptions as well ${ }^{20}$. Intussusceptions may be encountered 
in tropical sprue and coeliac patients, as well as in patients with abdominal trauma or during the post-operative period. There are cases in the literature with reported intussusception development in jejunum and ileum in the post truncal vagotomy period. Moreover, it is reported that intestinal intubation is another weighted factor in iatrogenic intussusception etiology $6,12,13,21,22$. No known etiology was detected for both of our study cases. Both of our cases were female contrary to most of the studies in the literature and the age range was 1 decade younger compared to the literature on the average. Small intestine originated intussusceptions detected in our study cases conform to the distribution rates specified in the literature in terms of being idiopathic and their localizations.

While the pathogenesis of intussusception is not known very well, it is based on the motility difference occurring in the adjacent two intestine segments. In case the proximal segment intussusception is in the distal segment, then it is called intussuscepient. It is possible to classify the known intussusceptions as enteric, ileo-colic and colonic based on the origin and fixation. Intussusceptions are named as anterograde and retrograde based on their direction of movement ${ }^{23-25}$. The cases in our study were assessed as enteric and ileo-colic based on the origin respectively, and as anterograde based on the direction of movement.

It is not easy to diagnose intussusception cases. The classic triple symptom triad vomiting, abdominal pain and bloody-stool, mainly encountered in children, is encountered in $15-20 \%$ of adults suffering from intussusception. While the symptoms of the adult patients during their application to the emergency service are non-specific; the most common is abdominal pain. Vomiting and rectal bleeding are the second most frequently encountered symptom with a rate of $71-90 \%$ in adults(26). The fact that the most characteristic feature of the abdominal pain encountered in $24-42 \%$ of the patient is being periodic and intermittent causes delay in intussusception diagnosis and merely a $30.7 \%$ correct diagnosis in the pre-operative period. The intestinal obstruction rate in adult intussusception making up $5 \%$ of all intussusceptions is merely $5 \%$. And emergency laparotomy rate is $20-61.5 \% 8,13,24,27,28$. While the symptoms of Case 2, the subject matter of our study, conform to the classic intussusception triad, there is a severe ileus pic- ture with dominant nausea-vomiting and abdominal swelling in Case 1 with severely developed intestinal obstruction. There was no delayed diagnosis in the pre-operative period of both cases since we were able to use the correct diagnostic methods efficiently and in a timely fashion, and our diagnosis rate was $100 \%$

DRI is capable of showing air-fluid levels or colon perforations of an intestinal obstruction developing depending on complicated intussusceptions ${ }^{8,9}$. Preoperative diagnosis values of preoperative ultrasound of the intestinal intussusception were found between $30-65 \%$ in different studies. It is possible to observe dilated and nested intestinal anses in abdominal US. The pseudo-kidney image revealed in the sagittal plane ultrasonography is not diagnostic for invagination albeit the high sensitivity and specificity. In transverse plane, target and oxeye images are assessed in favor of invagination ${ }^{3,23,29}$. The common use of $\mathrm{CT}$ as a diagnostic tool has a diagnostic accuracy rate of $50-80 \%$ in diagnosing intussusception in adults in the pre-operative period. CT scan is capable of showing the level of intussusception, influence level of intestines and necrosis threat indications. The classic target mass and sausage-shape images seen in the abdomen $\mathrm{CT}$ are valuable. However, they are not pathognomonic for intussusception(30). The final diagnosis for both cases was made using contrast enhanced Abdominal CT. the free air-fluid levels in the standing abdominal DRI performed for ileus in Case 1 and the target cell image and dilatation in ileum anses in the abdominal USG performed for Case 2 lead us to perform contrast enhanced abdominal CT. Abdominal CT scan showing the intussusception level and intestinal influence level was guiding for us to perform an explorative laparotomy.

While there is no specific diagnostic laboratory finding in intussusception cases, it is possible to observe leukocytosis and elevated CRP. There may be degradation of other biochemical parameters in complicated cases ${ }^{3,12,21}$. Degradation of hematologic and certain biochemical parameters of Case 1 in our study was attributed to an at least 3-day ileus development. Since Case 2 was diagnosed with non-complicated intussusception in the early period, hematologic and biochemical parameters were normal. 
While the treatment in children is non-operative barium hydrostatic reduction; surgery is the primary treatment method in almost all adult cases. The generally accepted opinion to find out the pathology underlying the adult intussusceptions is performing laparotomy. The matter of the need for reducing intussusceptions prior to reduction, the possibility of malign cells increasing the intraluminal and venous extensions and the reasons for increased perforation and anastomose complication risk shall be discussed along with the reasons $1,8,26,28,31$. It is possible to perform reduction prior to resection in certain colonic intussusception cases. Simple reduction is an acceptable method in post-traumatic and idiopathic intussusceptions provided that there is no lesion in the intestine. In case a malignancy is considered, acting more cautiously in terms of performing reduction prior to resection is advised. Accordingly, en bloc resection is advised $23,24,31,32$. The treatment decision for both assesses cases was adult surgery as recommended for most adults in the literature. However, while resection and primer anastomose is preferred in surgical treatment due to intussusception linked necrosis was developed in ileal anses in Case 1; reduction of solely the invaginated section was deemed appropriate for Case 2 in accordance with the intraoperative assessment. The reduction method preferred for very few cases in the literature due to the risks resulted in success in our case. There were no post-reduction complications observed.

The treatment of gastroduodenal intussusceptions is generally reduction and subsequent endoscopic surgical resection of the lesion line or laparotomy ${ }^{18}$. Reduction prior to resection is a preferred clinical approach provided that there is no malnutrition in intestine segment of coloanal intussusceptions. Sphincter protective approach in resection shall be preferred ${ }^{17,34}$. Colonoscopy may be performed in order to avoid unnecessary surgery in intussusceptions caused by colonic lesions such as appendix and polyp. It is possible to detect the starting point of ileo-colic, colo-colic and sigmoido-rectal intussusceptions using colonoscopy. It is possible to pathologically diagnose lesions such as adenoma and adenocarcinoma using the colonoscopy method ${ }^{3,35}$. However, non-mucosal lesions such as lymphoma and lipoma cannot be diagnosed with colonoscopy. Laparoscopic surgery on selected colo-rectal lipomas in the recent times may be an alternative to laparotomy. Surgical treatment may be difficult in gastroduodenal and colo-anal intussusceptions since it may require innovative methods ${ }^{19,33,36}$.

In conclusion, diagnosing and making differential diagnosis of adult intussusception may be difficult since it is not a common acute abdomen cause. CT scan is a gold standard in radiologic diagnosis. The surgical treatment is emergency laparotomy and resection for cases other than selected ones. It is possible to try the simple reduction in non-malnutrition intestine intussusception. Reduction prior to resection is not recommended due to dissemination, seeding and increased anastomose complications, particularly in colon intussusceptions in case malignancy is considered. 


\section{References}

1. Yalamarthi S, Smith RC. Adult intussusception:case reports and review of literature. Postgrad Med J 2005;81:174-7.

2. Korkmaz Ö, Yılmaz HG, Taçyıldız I, Baç B, Çevik S. Erişkinlerde Görülen İnvajinasyon Olgularının Değerlendirilmesi. Dicle Tıp Dergisi, 2007;34(3):182-6.

3. Wang N, Cui XY, Liu Y, Long J,Xu YH, Guo RX, Guo KJ. Adult intussusception:A retrospective review of 41 cases. World J Gastroenterol 2009;15(6):3303-8.

4. FelixEL, Cohen $M H$,Bernstein $A D$,et al. Adult intussusception: case report of recurrent intussusception and review of the literature.Am J Surg 1976;131:758-61.

5. Brooks A,Bebington BD, Lucas S,et al. Intussusception caused by blunt abdominal trauma. J Trauma 1999;47:156-7.

6. Eke N, Adotey JM. Postoperative intussusception, causal or casual relationship? Int Surg 2000;85:303-8.

7. Meyerson S,Desai TK,Polidori G,et al. A case of intussusception and lymphoid hyperplasia in a patient with AIDS. Am J Gastroenterol 1993;88:303-6.

8. Azar T, Berger DL. Adult intussusception. Ann Surg 1997;226:134-8.

9. Reijnen HA,Joosten HJ,DeBoer HH. Diagnosis and treatment of adult intussusception. Am J Surg 1989;158:25-8.

10. BoyleMJ, Arkell L J,Williams JT. Ultrasonic diagnosis of adult intussusception. Am J Gastroenterol 1993;88:617-8.

11. Bar- Ziv J, Solomon A. Computed tomography in adult intussusception. Gastrointest Radiol 1991;16:264-6.

12. Gayer G.Intussusception--not only a childhood disease. Isr Med Assoc J. 2001;3(12):962.

13. Erkan N, Haciyanli M, Yildirim M, Sayhan $H$, Vardar E, Polat AF. Intussusception in adults: an unusual and challenging condition for surgeons. Int J Colorectal Dis 2005; 20: 452-6.

14. Guillén Paredes MP, Campillo Soto A, Martín Lorenzo JG, et al. Adult intussusception-14 case reports and their outcomes. Rev Esp Enferm Dig 2010;102:32-40.

15. Karamercan A, Kurukahvecioglu O, Yilmaz TU, Aygencel G, Aytaç B, Sare M. Adult ileal intussusception: an unusual emergency condition. Adv Ther. $2006 ; 23(1): 163-8$.

16. Reijnen HA,Joosten HJ,De Boer HH. Diagnosis and treatment of adult intussusception. Am J Surg 1989;158:25-8.

17. Nesbakken A, Haffner J. Colo-recto-anal intussusception:casereport. Acta Chir Scand 1989;155:201-4.

18. Lin F,Setya V,Signor W. Gastroduodenal intussusception secondary to a gastric lipoma: a case report and review of literature. Am Surg 1992;58:772-4.

19. Atila K, Terzi C, Obuz F, Yılmaz T, Füzün M. Symptomatic intestinal lipomas requiring surgical interventions secondary to ileal intussusception and colonic obstruction: report of two cases. Ulus Travma Acil Cerrahi Derg
$2007 \cdot 13(3) \cdot 227-31$

20. Saïji E, Ayadi-Kaddour A, Ben Slama S, Ghariani B, Chelly-Ennaiffer I, Lahmar-Boufaroua A, Goutallier-Ben Fadhel C, Khalfallah MT, Mzabi-Regaya S.Inflammatory fibroid polyp of the ileum presenting as intussusception: a case report in an adolescent. Tunis Med. 2006 ;84(7):454-7.

21. M Athanasios, Yiallourou A, Samanides L, Dafnios N, Anastasopoulos G, Vassiliou I, Theodosopoulos T. Intussusception of the bowel in adults: A review. World J Gastroenterol 2009 28; 15(4): 407-11.

22. Youssef S, Jaidane M, Sakhri J, Belltaifa D, Kehila M.Intestinal invagination after vagotomy in adults. [Article inFrench] Ann Chir 2001;126:786-8.

23. Korkmaz Ö, Yılmaz HG, Taçyıldız İ, Akgün Y. Erişkinlerde İnvajinasyon. Ulus Travma Acil Cerrahi Derg 2009;15(2):154-8.

24. Toso C, Erne M, Lenzlinger PM, Schmid JF, Büchel H,Melcher G, et al. Intussusception as a cause of bowel obstruction in adults. Swiss Med Wkly 2005; 135:87-90.

25. Karahasanoglu T, Memisoglu K, Korman U, Tunckale A, Curgunlu A, Karter Y.Adult intussusception due to inverted M eck el's diverticulum:laparoscopic approach. Surg Laparosc Endosc Percutan Tech 2003;13:39-41.

26. Ahmad J, Lakomiec B, Loughrey MB. Image of the month. Spontaneous adult intussusception presenting as rectal bleeding.Clin Gastroenterol Hepatol. $2011 ; 9(2): A 18$.

27. Bilgin $F$, Özcan Ö, Dönmez M, Şentatar E, Ayşan E, Kaygusuz A. Yetişkinde Ince Bağırsak İnvajinasyonu: Nadir Bir Olgu.Bakırköy Tıp Dergisi2012;8:47-9.

28. Begos DG, Sandor A, Modlin IM. The diagnosis and management of adult intussusception. Am J Surg 1997;173:88-94.

29. Anderson DR. The pseudokidney sign. Radiology 1999;211:395-7.

30. David MW, MD and Joseph K.T. Lee, MD. Adult intussusception detected at CT or MR imaging: clinical-imaging correlation. Radiology. 1999;212: 853-60.

31. Lebeau R, Koffi E, Diané B, Amani A, Kouassi JC. Acute intestinal intussusceptions in adults: analysis of 20 cases.Ann Chir 2006; 131:447-50.

32. Kitamura K, KitagawaS,Mori M,et al. Endoscopic correction of intussusception and removal of a colonic lipoma. Gastrointest Endosc 1990;36:509-11.

33. Barussaud M, Regenet N, Briennon X, et al. Clinical spectrum and surgical approach of adult intussusceptions: a multicentric study.Int J Colorectal Dis. 2006;21(8):834-9.

34. Nagomey DM,Sarr MG, Mc Irath DC. Surgical management of intussusception in the adult. Ann Surg 1981;193:230-6.

35. Zubaidi A, Al-Saif F, Silverman R. Adult intussusception: a retrospective review. Dis Colon Rectum 2006; 49: 1546-51.

36. El-Khalil T, Mourad FH, Uthman S. Sigmoid lipoma mimicking carcinoma: case report with review of diagnosis and management. Gastrointest Endosc 2000;51(4 Pt 1):495-6. 